\title{
SUKSES BERINTERAKSI DENGAN ANAK TIRI (Studi Kasus Nabi Shallallahu 'alaihi wa sallam Bersama Anak Tiri Beliau)
}

\author{
Muhamad Arifin \\ Program Studi Ahwal Syakhsiyyah \\ Sekolah Tinggi Dirasat Islamiyah Imam Syafi’i Jember \\ wongbringin@gmail.com
}

\begin{abstract}
The existence of stepchild in a household is often the source of the household disharmony between husband and wife. It is common for this disharmony to lead to divorce. On the other hand, the stepchild often receives discriminatory and even cruel treatment. By using the descriptive analysis method, the author collected the data on the life of the Prophet -peace and blessings of Allah be upon him- with his stepchildren. Then the data were analysed, in order to reveal his practical and applicabletips from living with the stepchildren. The author madethe Prophet life with his stepchildren the object of research, asthe Prophet is a role model for mankind in every aspect of life. He had of course taught a set of applicable and effective tips in living a married life with his stepchildren. Moreover, he married ten widowed women who all had children from their previous marriage. From analysing these data, the author found at least six practical tips that the Prophet exemplified so that he succeeded in interacting with all of his stepchildren.From this research, the author concluded that one of the solutions to the success of the Prophet -peace and blessings of Allah be upon him-in interacting with his stepchildren is because he positioned them as one of the keys to the Prophet's marriage with their mothers and as one of the keys to happiness in the household. Likewise, the Prophet never perceived his stepchildren as a threat to the peace of his household.
\end{abstract}

Keywords: stepchild, stepparent, widow, biological child, household.

\begin{abstract}
ABSTRAK
Keberadaan anak tiri dalam suatu rumah tangga sering kali menjadi biang terjadinya keretakan hubungan antara suami dan istri. Tidak jarang keretakan tersebut berujung dengan perceraian. Di sisi lain, anak tiri sering kali mendapat perlakuan diskriminatif bahkan bengis. Dengan menggunakan metode diskriptif analisis, penulis mengumpulkan data kehidupan Rasulullah shallallahu 'alaihi wa sallam bersama anak-anak tiri beliau. Selanjutnya data-data tersebut dianalisis, guna mengungkap kiat-kiat praktis aplikatif dari kehidupan bersama anak-anak tiri beliau. Penulis menjadikan kehidupan beliau bersama anak-anak tiri beliau sebagai objek penelitian, karena beliau adalah teladan umat manusia dalam setiap sendi kehidupan. Sudah barang tentu beliau telah mengajarkan seperangkat kiat aplikatif dan efektif dalam menjalani kehidupan berumah tangga bersama anak-anak tiri beliau. Terlebih lagi, beliau menikahi sepuluh wanita janda yang semuanya memiliki anak keturunan dari suami sebelum beliau. Dari menganalisa data-data tersebut, penulis sedikitnya menemukan enam kiat praktis yang beliau contohkan sehingga berhasil dalam berinteraksi dengan semua anak tiri beliau. Dari penelitian ini, penulis menyimpulkan bahwa salah satu kunci sukses Rasulullah shallallahu 'alaihi wa sallam berinteraksi dengan anak tiri beliau ialah karena beliau memposisikan anakanak tirinya sebagai salah satu kunci terjadinya pernikahan beliau dengan orang tua mereka dan sebagai salah satu kunci kebahagiaan dalam rumah tangganya. Sebagaimana juga beliau
\end{abstract}


tidak pernah mempersepsikan anak-anak tiri beliau sebagai ancaman bagi kedamaian rumah tangganya.

Kata Kunci: anak tiri, orang tua tiri, janda, anak kandung, rumah tangga.

\section{A. PENDAHULUAN}

Biasanya, keluarga inti terdiri dari suami, istri dan anak kandung mereka. Namun itu bukan satu hal yang baku, karena di masyarakat banyak keluarga yang terdiri dari anggota selain mereka, di antaranya adalah anak tiri. Walaupun anak tiri sejatinya adalah anak kandung bagi salah satu pasangan suami istri, namun tetap saja ia adalah orang lain bagi suami atau istri orang tuanya.

Ada dua kejadian yang sering melatar belakangi adanya anak tiri dalam suatu keluarga. Alasan pertama, karena salah satu orang tua anak tersebut meninggal dunia, dan kemudian orang tuanya menikah lagi dengan pasangan lain. Ada kalanya kedua orang tuanya bercerai, dan kemudian masing masing menikah dengan pasangan yang lain.

Apapun latar belakangnya, keberadaan anak tersebut bersama salah satu orang tuanya yang telah menikah dengan pasangan lain, seringkali diiringi banyak masalah.Di masyarakat telah berkembang persepsi bahwa orang tua tiri itu bengis, kejam, pilih kasih, dan sering melakukan kekerasan kepada anak-anak tirinya (Noviana, 2015: 16).

Ada banyak dongeng, berita bahkan tembang atau film yang menggambarkan akan buruknya perilaku orang tua tiri. Berbagai hal tersebut kemudian menjadi alasan bagi sebagian janda atau duda enggan untuk menikah kembali, karena mengawatirkan nasib anak kandungnya bila tinggal serumah dengan orang tua tiri (Arifin, 2019: 21).

Sebagian orang, sebelum memutuskan untuk menikah lagi, dengan pasangan lain, ia bersyarat agar calon pasangannya menerima anak kandungnya tinggal serumah dengannya dan memperlakukannya bagaikan anak kandungnya sendiri. Namun dalam banyak kasus, faktanya tidak seindah yang disepakati sebelum keduanya menikah.

Karena itu penulis tertarik untuk menggali data dalam kehidupan Nabi sallallahu 'alaihi wa sallam yang dalam kehidupan rumah tangga beliau terdapat beberapa anak tiri. Dari berbagai referensi, ditemukan ada beberapa anak tiri beliau, yaitu:

1. Hind bin Abi Hālah

2. Al Harits bin Abi Hālah

3. Hālah bin Abi Hālah.

4. Ṭāhir bin Abi Hālah 
5. Habībah bintu 'Ubaidillah bin Jahesy.

6. Zaenab bintu Abi Salamah

7. 'Umar bin Abi Salamah

8. Salamah bin Abi Salamah.

9. Ummu Kulșum bintu Abi Salamah

Penelitian ini bertujuan untuk mengungkap beberapa hal berikut ini: (1) Metode aplikatif Nabi șallallahu 'alaihi wa sallam dalam menjaga keharmonisan rumah tangga beliau tanpa terganggu oleh keberadaan anak tiri bersamanya, (2) Solusi jitu yang dicontohkan oleh Nabi shallallahu 'alai wa sallam dalam mencegah terjadinya tindak kelaliman kepada anak tiri, (3) Keteladanan Nabi șallallahu 'alaihi wa sallam dalam mendidik anak tiri agar mereka dapat tumbuh kembang menjadi anak sholeh dan sholehah.

\section{B. METODE PENELITIAN}

Untuk mencapai tujuan tujuan penelitian di atas, penulis menggunakan metode deskriptif analisis, dengan mengumpulkan berbagai data yang didapat. Selanjutnya data- data tersebut dianalisa untuk mendapatkan gambaran sistematis dan akurat tentang kiat kiat Nabi sallallahu 'alaihi wa sallam dalam berinteraksi dengan anak-anak tiri beliau. Dengan terungkapnya gambaran sistematis tentang model interaksi Beliau șallallahu 'alaihi wa sallam, maka dapat menjadi role model bagi setiap orang yang hidup serumah dengan anak tirinya.

Ruang lingkup penelitian ini, adalah hubungan antara Nabi șallallahu 'alaihi wa sallam dengan anak-anak tiri beliau. Dengan mengambil topik kiat kiat Rasulullah sallallahu 'alaihi wa sallam dalam berinteraksi dengan anak tiri. Dengan demikian obyek penelitian ini adalah Rasulullah șallallahu 'alaihi wa sallam dan anak-anak tiri beliau. Sedangkan subyek penelitian ini adalah sikap sikap Rasulullah șallallahu 'alaihi wa sallam kepada anak tiri beliau.

\section{HASIL DAN PEMBAHASAN}

\section{Kewajiban Menjaga Nasab}

Salah satu ketentuan baku dalam syari'at Islam yang berkaitan dengan anak adalah status nasab yang diikuti dengan tetapnya hak dan tanggung jawab masing masing. Berbagai ketimpangan dan penyimpangan dalam urusan anak dan istri,seringkali berawal dari kebodohan berbagai pihak tentang status dirinya dan kewajiban yang bertautan dengan status tersebut. 
Islam menetapkan bahwa nasab anak dihubungkan dengan ayah kandungnya. Terhubungnya nasab antara anak dan ayah kandungnya bukan sekedar hak anak, namun juga hak sang ayah kandung. Anak berhak mengklaim nasabnya kepada sang ayah, dan sang ayah berhak mengklaim nasabnya atas sang anak. Karena itu keduanya hak saling mewarisi dan berkewajiban menanggung denda pembunuhan yang dilakukan oleh salah satu dari keduanya.

Dalam hukum waris, hak saling mewarisi antara ayah dan anak ini tidak dapat terhalangi oleh siapapun selain mereka. Bahkan sebaliknya, ayah atau anak dapat menghalangi selain mereka dari mendapatkan hak waris (Al Fauzan, 1987: 69).

Rasulullah șallallahu 'alaihi wa sallam menegaskan bahwa nasab adalah hak ayah dengan sabdanya:

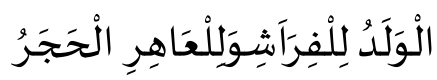

Anak adalah milik lelaki pemilik ranjang, sedangkan pezina itu tidak berhak memiliki apa-apa. (Al Bukhari, 1987: 724)

Di sisi lain, Rasulullah șallallahu 'alaihi wa sallam juga menjelaskan bahwa adanya hubungan nasab sebagai ayah, menjadikannya berhak atas harta kekayaan anaknya. Hak seorang ayah atas harta anaknya ini, bukan hanya melalui jalur warisan, bahkan jauh hari sebelum sanganak meninggal dunia, sang ayah berhak untuk turut serta menggunakan harta kekayaan anaknya.

Ada seorang lelaki yang mengadukan sikap ayah kandungnya yang mengambil harta sang anak. Lelaki itu mengadukan sikap tindakan ayah kandungnya, karena ia memiliki anak keturunan yang harus ia nafkahi. Semula ia menduga bahwa ia hanya berkewajiban untuk menafkahi anak-anaknya, sehingga ia jengah dengan tindakan ayah kandungnya.

Menjawab pengaduan lelaki tersebut, Nabi șallallahu 'alaihi wa sallam bersabda:

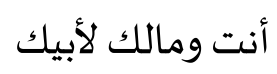

Engkau beserta seluruh hartamu adalah milik ayahmu. (Al Syaibani: 204)

Lebih jauh beliau menjelaskan alasan ketetapan ini dengan bersabda:

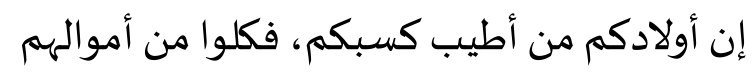

Sesungguhnya anak-anak kalian adalah salah satu penghasilan kalian yang paling baik, maka silahkan engkau turut menggunakan harta kekayaan mereka. (Al Syaibani: 214) 
Hubungan nasab antara orang tua dan anak ini harus dijaga, karena syari'at Islam memerintahkan kita untuk menjaga keutuhan nasab. Salah satu sarana agar keutuhan nasab dapat terjaga dan hak-haknya tertunaikan dengan sempurna ialah dengan mengenali nasab dirinya masing masing.

Tanpa mengenali nasab niscaya siapapun tidak dapat menunaikan dengan baik, hak dan kewajibannya terhadap semua orang yang terhubung nasab dengannya. Rasulullah șallallahu 'alaihi wa sallam bersabda:

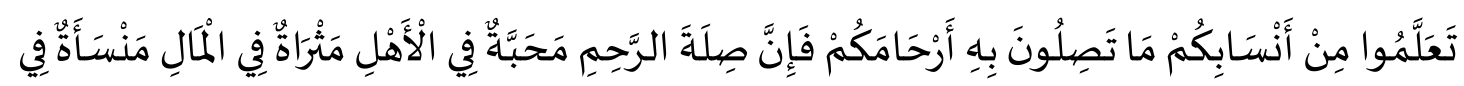

Kenalilah nasab kalian, agar dengan mengenalinya kalian dapat menyambung tali silaturrahim kalian. Karena sejatinya menyambung tali silaturrahim itu dapat menyuburkan kasih sayang dalam keluarga, mendatangkan kekayaan dan memanjangkan umur. (Al Syaibani: 374)

\section{Larangan Merusak Nasab}

Sebagaimana menjaga nasab adalah satu kewajiban atas setiap insan, maka merusaknya adalah tindak kejahatan besar dalam islam. Islam mengancam dengan keras orang yang mengabaikannya, dengan mengabaikan hak-hak nasab, apalagi sampai mengingkarinya.

Banyak dalil dalam Al Qur'an ataupun hadị̦ Nabi șallallahu 'alaihi wa sallam yang menggambarkan betapa berat dosa orang yang mengabaikan hak-hak nasab, hingga akhirnya terputus. Disebutkan pada satu riwayat bahwa orangyang memutus tali silaturrahim tidak dapat masuk surga (Al Bukhari, 1987: 2231).

Di antara bentuk merusak nasab ialah dengan mencampuradukkannya, sehingga kemurnian nasab tidak dapat dipertanggungjawabkan. Percampuradukan nasab dapat terjadi akibat dari hubungan di luar pernikahan, atau perselingkuhan, atau menikahi wanita yang sedang dalam kondisi hamil.

Sebaliknya juga demikian, lelaki yang semena-mena mengingkari nasab anak keturunannya, tanpa bukti yang dapat dipertanggungjawabkan, mendapat ancaman keras.

Rasulullah șallallahu 'alaihi wa sallam bersabda:

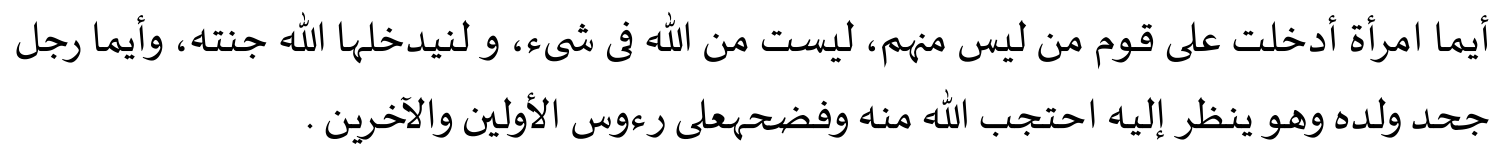


Siapapun wanita yang menyusupkan seorang anak kedalam nasab suatu kaum (kabilah) padahal ia bukan berasal dari mereka, maka ia tidak mendapat bagian dari rahmat Allah sedikitpun dan Allah tidak akan memasukkannya ke dalam surga-Nya. Siapapun lelaki yang mengingkari anak keturunannya, sedangkan ia mengenalinya, maka Allah tidak sudi melihatnya, dan Allah akan mempermalukannya di hadapan semua orang. (Al Sajistani: 246)

Di antara bentuk merusak nasab ialah dengan menasabkan diri atau orang lain kepada selain nasabnya. Di zaman jahiliyah, tindakan menasabkan diri kepada orang lain, salah sat unya kepada ayah angkat adalah satu hal yang biasa terjadi.

Dikisahkan bahwa Nabi șallallahu 'alaihi wa sallam mengambil anak angkat bernama Zaid bin Al Ḥarișah, sehingga sahabat Zaid kemudian selalu dikenal dengan panggilan Zaid bin Muhammad șallallahu 'alaihi wa sallam (Al Naisaburi: 130).

Tindakan seperti ini dilakukan secara luas dan turun temurun oleh masyarakat Arab kala itu.Anak angkat diperlakukan bagaikan anak kandung, sehingga memiliki hak mewarisi dan juga hak-hak lain sewajarnya anak kandung.

Karena tindakan ini memiliki dampak buruk yang sangat besar, maka Islam mengharamkannya, dan menghapuskan budaya menasabkan anak angkat kepada lelaki yang mengangkatnya sebagai anak.. Allah Ta'ala berfirman:

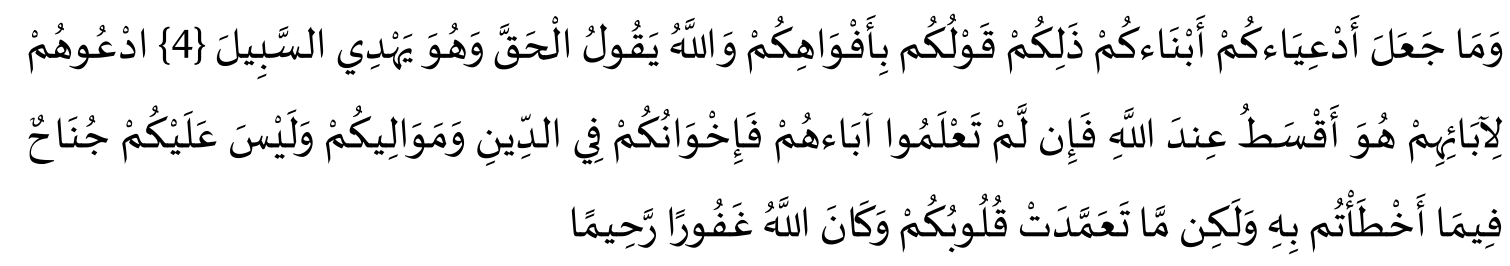

Dia Allah tidak sekali kali menjadikan anak-anak angkatmu sebagai anak kandungmu (sendiri). Yang demikian itu hanyalah perkataanmu di mulutmu saja. Dan Allah mengatakan yang sebenarnya dan Dia menunjukkan jalan (yang benar).Panggillah mereka (anak-anak angkat itu) dengan (memakai) nama bapak-bapak mereka; itulah yang lebih adil pada sisi Allah, dan jika kamu tidak mengetahui bapak-bapak mereka, maka (panggillah mereka sebagai) saudara-saudaramu seagama dan maula-maulamu. Dan tidak ada dosa atasmu terhadap apa yang kamu khilaf padanya, tetapi (yang ada dosanya) apa yang disengaja oleh hatimu. Dan adalah Allah Maha Pengampun lagi Maha Penyayang. (Q.S. Al Ahzab: 4-5)

Sejak turunnya ayat ini, Islam melarang praktek menasabkan anak angkat kepada lelaki yang mengasuhnya (ayah angkatnya). Sebagai gantinya, mereka diperintahkan untuk mengembalikan nasab anak-anak angkat tersebut kepada ayah kandung mereka, demikian Imam Ibnu Kașir menjelaskan maksud ayat di atas (Ibnu Kasir: 1999: 377). 
Dalam sejarah rumah tangga Nabi salallahu 'alaihi wa sallam tidak satupun dari anak tiri beliau yang dinasabkan kepada diri beliau. Hanya sahabat Zaid bin Al Ḥārisah raḍiallahu 'ahu saja yang semula dinasabkan kepada Nabi șallallahu 'alaihi wa sallam.

Perbedaan sikap Nabi șallallahu 'alaihi wa sallam tersebut patut dikaji secara mendalam. Padahal keberadaan anak tiri dalam rumah tangga Nabi șallallahu 'alaihi wa sallam telah ada sejak pernikahan pertama beliau, yaitu dengan Khadijahraḍillahu 'anha.

Dari berbagai referensi, penulis menemukan bahwa ketika menikah dengan Rasulullah șallallahu 'alaihi wa sallam telah memiliki empat orang anak dari suami sebelum beliau, yaitu Nabbasy bin Zurārah At Tamimi. Keempat anak tersebut adalah :

1. Hind bin Abi Hālah

2. Al Hāarits bin Abi Hālah

3. Hālah bin Abi Hālah.

4. Tāhir bin Abi Hālah

\section{Kiat Nabi Sallallahu 'alaihi wa sallam Berinteraksi Dengan Anak Tirinya}

Dari data sejarah yang berhasil penulis rangkum, baik dari refensi referensi hadị̦, sīroh, tārikh maupun tarājum ulama', tidak ditemukan ada kendala pada hubungan beliau dengan mereka. Bahkan penulis menemukan sebaliknya, yaitu data-data yang menunjukkan hubungan yang sangat harmonis.Sebagaimana keberadaan anak tiri dalam rumah tangga beliau tidak mengganggu keharmonisan hubungan beliau dengan istri-istri beliau, sampaipun dengan ibu dari anak-anak tiri tersebut.

Setelah mengkaji berbagai data yang terkumpul, penulis menemukan beberapa kiat yang beliau contohkan dalam berinteraksi dengan anak tiri. Kiat-kiat itu menjadi salah satu kunci rumah tangga beliau tetap harmonis. Berikut kiat-kiat yang berhasil penulis simpulkan:

a. Kiat pertama: Memfungsikan nasab anak tiri

Nasab memiliki arti yang sangat besar dalam syari' at Islam. Salah satu manfaatnya ialah peran wali dalam mengasuh, menafkahi dan mendidik anak-anak tersebut. Peran wali anak tersebut semakin dominan sejak ibu mereka menikah dengan lelaki lain.

Dengan menjalankan peran nasab dan perwalian ini, tanggung jawab mengasuh anak tidak menjadi beban bagi ayah tirinya, terlebih ayah tiri dengan tingkat kesibukan dan tanggung jawab yang besar, sebagaimana yang terjadi pada diri Nabi sallallahu 'alaihi wa sallam, atau keterbatasan finansial. 
Penulis mensinyalir bahwa alasan ini menjadi sebab tidak adanya anak tiri beliau yang dinasabkan kepada diri beliau, walaupun mereka telah ada dalam kehidupan rumah tangga Rasulullah șallallahu 'alaihi wa sallam sejak pernikahan pertama beliau. Di sisi lain, dengan berfungsinya peran nasab maka tanggung jawab atas mereka, dipikul oleh para wali bukan ibu kandung mereka.

Dengan demikian, ibu anak tersebut dapat fokus melayani suaminya tanpa terbebani oleh kewajiban mengasuh anak kandungnya. Kiat ini sejalan dengan jawaban Rasulullah sallallahu 'alaihi wa sallam kepada seorang wanita yang bersengketa dengan mantan suaminya, memperebutkan hak asuh atas anak mereka. Beliau bersabda:

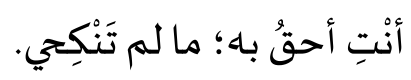

Engkau lebih berhak mengasuh dia, selama engkau belum menikah kembali. (Al Sajistani, 1418: 251)

Ketika ibu kandung anak tersebut telah menikah dengan lelaki lain, maka kesibukannya menunaikan hak-hak suaminya, menjadikannya kurang mampu mengasuh anaknya. Dari emosional kekeluargaan, wali anak tersebut merasa terhina bila salah satu anggota inti keluarga besar mereka hidup dibawah tanggungan orang lain, demikian Imam Al Mawardi menjelaskan (Al Mawardi, 1994: 505).

Dari beberapa nama anak tiri beliau, penulis menemukan hanya beberapa orang saja, yaitu Umar bin Abi Salamah dan Salamah bin Abi Salamah yang tinggal serumah dengan beliau.Adapun selain keduanya, penulis tidak menemukan data yang menunjukkan bahwa mereka tinggal serumah dengan Nabi sallallahu 'alaihi wa sallam.

Kesimpulan ini, sejalan dengan ketentuan syari'at bahwa wanita yang telah menikah dengan lelaki lain, kehilangan hak asuh terhadap anaknya. Menurut Ibnu Taimiyah, ketentuan ini bertujuan agar suami wanita itu tidak mengintervensi urusan pengasuhan anak-anak tersebut, apalagi sampai mengeksploitasinya (Ibnu Taimiyah: 328).

Semasa hidup ayah kandungnya, secara alami, maka seorang anak akan berada dalam pengasuhan ayah kandungnya. Namun sepeninggal sang ayah, maka akan ada banyak pihak yang mengancam atau mengganggu anak tersebut. Sehingga pada kondisi semacam ini nasab benar-benar berperan sehingga sang anak mendapat pembelaan dan bantuan dari keluarga terdekatnya. Masih menurut Ibnu Taimiyah, orang yang paling potensial membela 
dan melindungi ialah ayah dan kerabat laki laki terdekat anak tersebut, atau yang dalam ilmu fiqih dikenal dengan sebutan aṣabah (Ibnu Taimiyah: 308).

Dalam kehidupan manusia, pengasuhan dan perlindungan adalah salah satu konsekuensi alami dari adanya hubungan kekerabatan. Menurut Ibnu Kholdūn, setiap orang akan tergugah untuk membela kerabatnya yang sedang terancam atau mengalami kesusahan. Setiap kerabat merasa sakit hati bila mengetahui ada kerabatnya yang dizhalimi atau dimusuhi. Tanpa dipintapun, ia akan bangkit untuk membela atau membantu kerabatnya menghadapi ancaman atau tindak kelaliman tersebut. Semakin dekat hubungan kekerabatan antara dua orang, maka semakin kuat keinginan mereka untuk saling melindungi dan membela (Ibnu Kholdun: 129).

Di antara data yang menguatkan analisa penulis ini ialah sejarah kehidupan Rasulullah sallallahu 'alaihi wa sallam semasa kecil beliau. Beliau dilahirkan dalam keadaan yatim, karena ayah beliau meninggal dunia semasa beliau masih dalamkandungan ibunya. Seusai melalui masa masa persusuan di Bani Sa'diyah selama empat tahun, beliau diasuh kembali oleh ibunya Āminah, hingga berumur enam tahun. Ketika ibunya meninggal dunia, maka kakeknya yang bernama Abdul Muṭtaliblah yang mengasuh beliau hingga sang kakek meninggal dunia.

Sepeninggal Abdul Muțțalib, beliau diasuh oleh pamannya yang bernama Abu Ṭālib. Sang paman merasa paling bertanggung atas pengasuhan Nabi șallallahu 'alaihi wa sallam padahal beliau sendiri dalam kondisi miskin dan memiliki anak keturunan yang banyak, sebagaimana dikisahkan dalam berbagai referensi sirah Nabi șallallahu 'alaihi wa sallam.

Perlindungan dan pembelaan Abu Ṭālib kepada Nabi șallallahu 'alaihi wa sallam bukan yang semasa beliau masih kecil. Abu Ṭālib terus membela dan melindungi keponakannya hingga akhir hayatnya, walaupun ia enggan untuk mengucapkan syahadat, dan akhirnya mati dalam keadaan kafir (Al Mubarakfuri: 48).

b. Kiat kedua: Melibatkan orang tua asuh atau ibu persusuan

Dikisahkan bahwa Ummu Salamah radiallahu 'anha, menolak secara halus lamaran Rasulullah șallallahu 'alaihi wa sallam. Ada beberapa alasan yang beliau utarakan, salah satunya perihal anak-anak beliau.

Mendengar alasan tersebut, Rasulullah șallallahu 'alaihi wa sallam bersabda:

$$
\text { هم إلى الله والى رسوله : - ت }
$$

Serahkan urusan mereka kepada Allah dan kepada Rasul-Nya. (Al Syaibani: 320) 
Rasulullah șallallahu 'alaihi wa sallam menjelaskan bahwa urusan anak-anak Ummu Salamah bukan urusan beliau.Sesuai ketentuan syari'at Allah dan Rasul-Nya mereka adalah tanggung jawab wali-walinya, demikian Ibnu Kașir menjelaskan maksud ḥadị di di as (Ibnu Kaṣir, 1988: 92).

Setelah semua alasan Ummu Salamah radiallahu 'anha terjawab, maka Rasulullah șallallahu 'alaihi wa sallam menikahinya. Namun setiap kali Rasulullah șallallahu 'alaihi wa sallam hendak mendatangi Ummu Salamahraḍiallahu 'anha, selalu saja beliau sedang menyusui putrinya; yaitu Zaenab bintu Abi Salamah raḍiallahu 'anha. Merasa iba kepada Zaenab bintu Abi Salamah, maka Rasulullah șallallahu 'alaihi wa sallam memilih untuk pergi.

Tanggap dengan permasalahan yang terjadi, sahabat 'Ammar bin Yaasir radhiallahu 'anhu menemui Ummu Salamah dan meminta agar Zaenab binti Abi Salamah diserahkan kepada dirinya, untuk dicarikan ibu susuan.

Ketika Rasulullah șallallahu 'alaihi wa sallam datang kembali, beliau heran karena tidak menemukan Zaenab bersama Ummu Salamah. Beliaupun bertanya: dimanakah Zaenab? Ummu Salamah menjelaskan bahwa Zaenab putrinya telah dibawa oleh Ammār bin Yāsir dan diserahkan kepada ibu susuannya (Al Syaibani: 321).

Walau semula keputusan menyerahkan Zaenab binti Abu Salamah kepada ibu susuan adalah tindakan sahabat Ammār bin Yāsir. Namun demikian, Rasulullah șallallahu 'alaihi wa sallam merestui tindakannya ini. Sehingga secara tinjauan ilmu hadị̣ tindakan tersebut dikategorikan sebagai bagian dari keputusan Rasulullah sallallahu 'alaihi wa sallam. Alasannya, bila tindakan sahabat Ammār bin Yāsir tersebut salah, niscaya Rasulullah sallallahu 'alaihi wa sallam tidak tinggal diam. Mengingat beliau berkewajiban menjelaskan syari'at, sedangkan menunda penjelasan saat dibutuhkan adalah satu tindakan yang telarang, sebagaimana dijelaskan oleh para ulama' ahli ilmu ushul fiqih (Al Ghazali, 1413: 192).

Adapun anak tiri yang ayah kandungnya masih hidup, maka sudah barang tentu anak tersebut berada dalam pengasuhan ayah kandungnya. Sehingga dengan sendirinya mereka tidak menjadi masalah bagi hubungan pernikahan ibu kandung mereka dengan Rasulullah șallallahu 'alaihi wa sallam; ayah tiri mereka. 
c. Kiat ketiga:Komitmen menerima anak tiri sejak awal pernikahan

Pernikahan adalah ikatan atau akad yang menyatukan antara suami dan istri. Sehingga dengan akad pernikahan itu, keduanya berkomitmen untuk menunaikan kewajiban masingmasing dengan sekuat tenaga, demikian perintah Allah Ta'ala pada ayat berikut:

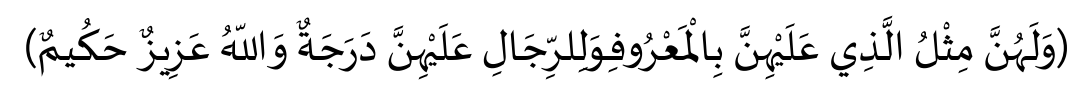

Dan para wanita mempunyai hak yang seimbang dengan kewajibannya menurut cara yang makruf. Akan tetapi para suami mempunyai satu tingkatan kelebihan daripada istrinya. Dan Allah Maha Perkasa lagi Maha Bijaksana. (QS. Al Baqarah: 228)

Ayat ini memerintahkan masing masing suami dan istri agar menunaikan hak-hak pasangannya secara maksimal, sesuai dengan standar kelayakan yang berlaku di masyarakat mereka, demikian Ibnu Kașir menjelaskan (Ibnu Kașir, 1988: 199).

Pada ayat ini juga dijelaskan bahwa kewajiban masing masing suami dan istri sebanding dengan hak mereka. Sebagian ulama' menjelaskan bahwa yang dimaksud dengan hak istri sebanding dengan kewajibannya adalah dalam hal-hal berikut:

1) Hak ditunaikan secara baik sesuai standar kelayakan yang berlaku di masyarakat.

2) Hak-hak tersebut ditunaikan tanpa ada penundaan.

3) Menunaikan hak dengan suka rela, riang hati dan mimik wajah yang memancarkan rasa bahagia.

4) Tidak mengungkit-ungkit hak yang ditunaikan oleh masing masing dari keduanya (Al Maqdisi, 1997: 220).

Di antara hal yang wajib dipenuhi oleh suami dan istri ialah hal-hal yang dipersyaratkan oleh salah satu dari mereka. Karena syarat-syarat tersebut menjadi bagian yang tak terpisahkan dari akad pernikahan mereka. Rasulullah șallallahu 'alaihi wa sallam bersabda:

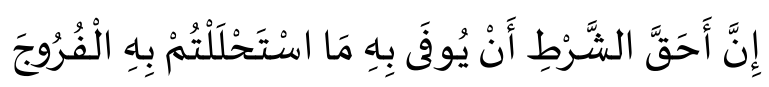

Sejatinya persyaratan yang paling wajib untuk engkau penuhi adalah persyaratan yang telah engkau sepakati untuk menjadikan kemaluan wanita halal bagi diri kalian (AlBukhari, 1987: 970).

Ḥadiṣ ini menegaskan bahwa persyaratan yang telah disepakati antara suami danistri adalah persyaratan yang paling utama untuk dipenuhi, dibanding persyaratan yang disepakati pada akad selainnya (Al-Mawardi, 1994: 505). 
Dalam kaitan dengan pernikahan Rasulullah șallallahu 'alaihi wa sallam dengan Ummu Salamah, maka hal ini penting dicermati. Mengingat sejak proses lamaran, Ummu Salamah raḍiallahu 'anha telah membicarakan perihal mereka dengan Rasulullah shallallahu 'alaihi wa sallam. Ummu Salamah berkata: "Sejatinya aku adalah seorang janda yang memiliki banyak anak."

Atas permasalahan itu, Rasulullah șallallahu 'alaihi wa sallam, mengutarakan komitmen untuk menerima kehadiran mereka bahkan bertanggung jawab atas urusan mereka, seakan mereka adalah keluarga beliau sendiri. Rasulullah șallallahu 'alaihi wa sallam bersabda:

$$
\text { هم إلى الله والى رسوله }
$$

Serahkan urusan mereka kepada Allah dan kepada Rasul-Nya (Al-Syaibani: 320).

Pada redaksi riwayat lain Rasulullah șallallahu 'alaihi wa sallam mengutarakan komitmen beliau akan mencukupi urusan mereka. Beliau bersabda:

$$
\text { فستكفين صبيانك }
$$

Urusan anak anakmu, maka engkau akan dicukupi dalam urusan mereka (Al-Syaibani: 317).

Pada redaksi lain dari riwayat ini, Rasulullah șallallahu 'alaihi wa sallam bersabda:

$$
\text { وأما ما ذكرت من العيال فإنما عيالك عيالي }
$$

Adapun alasan yang engkau sebutkan perihal anak anakmu, maka sesungguhnya anak anakmu bagaikan anak anakku sendiri (Al-Syaibani: 27).

Kesepakatan antara Rasulullah șallallahu 'alaihi wa sallam bersama Ummu Salamah ini menjadi landasan dalam hubungan beliau berdua dengan anak-anak Ummu Salamah dari suami sebelumnya. Komitmen Rasulullah șallallahu 'alaihi wa sallam di atas dapat diteladani oleh siapapun oleh yang hendak menikahi atau menikah dengan calon pasangan yang telah memiliki anak keturunan dari pasangan sebelumnya. Umar bin Abi Salamah raḍiallahu 'anhu, salah satu dari anak tiri beliau, sedikit menceritakan bagaimana Rasulullah șallallahu 'alaihi wa sallam menyikapi dirinya. Suatu hari, Nabi șallallahu 'alaihi wa sallam memanggilnya untuk turut menyantap hidangan beliau. Rasulullah sallallahu 'alaihi wa sallam memanggilnya dengan bersabda:

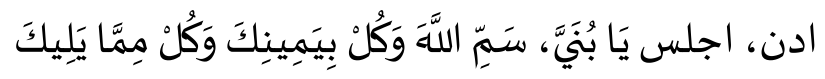


Mendekat dan duduklah, wahai anakku! Sebutlah Nama Allah, makanlah dengan tangan kanan, dan makanlah dari yang terdekat dari dirimu. (Al Busti, 1993: 19)

Beliau memintanya untuk mendekat, lalu duduk memanggilnya dengan penuh kasih sayang: "wahai anakku”. Sikap Rasulullah shallahu 'alaihi wa sallam ini tentu menjadikan Umar bin Abi Salamah merasa akrab, bagaikan berhadapan dengan ayah kandungnya. Setelah sahabat Umar bin Abi Salamah merasa akrab, Rasulullah șallallahu 'alaihi wa sallam mulai mengajarkan perilaku yang benar ketika makan. Senantiasa menyebut nama Allah Azza wa Jalla setiap kali hendak makandan makan dengan tangan kanan.

Pendidikan ini benar-benar meresap ke dalam diri sahabat Umar bin Abi Salamah radhiallahu 'anhu.Sejak saat itu, sahabat Umar bin Abi Salamah menerapkan pendidikan ayah tirinya tersebut. Beliau berkata: "Itulah tata cara aku makan hingga saat ini" (Al Syaibani: 25).

Padahal sebelumnya, sahabat Umar bin Abi Salamah raḍillahu 'anhuma memiliki kebiasaan buruk ketika makan. Beliau menjulurkan tangannya ke berbagai sudut nampan. Namun sekali mendapat arahan dari ayah tirinya, beliau meninggalkan kebiasaan buruk tersebut untuk selamanya.

d. Kiat keempat: Memahami peran sentral anak tiri pada pernikahan dirinya

Seorang janda berhak menentukan pilihan, apakah akan menikah kembali atau tetap menjada. Salah satu alasan kuat seorang janda ketika menjatuhkan pilihannya, ialah nasib atau sikap anak-anak kandungnya. Betapa banyak wanita yang memilih untuk mempertahankan statusnya sebagai janda demi anak anaknya. Sebaliknya juga demikian, betapa banyak janda yang memutuskan untuk menikah lagi, demi masa depan anak anaknya.

Peran anak-anak sang janda tersebut semakin besar dan vital, bila mereka telah menginjak umur dewasa. Betapa banyak anak-anak yang tidak rela dan berusaha sekuat tenaga menghalangi ibu kandung mereka menikah dengan lelaki lain sepeninggal ayah kandung mereka (Arifin, 2019: 19).

Ditambah lagi menurut mayoritas ulama' termasuk Imam Muzani murid Imam As Syāfii, anak kandung laki laki wanita janda tersebut adalah salah satu yang berhak menjadi wali ibunya. Sehingga peran mereka sangatlah vital bagi terjalinnya pernikahan seorang lelaki dengan ibu kandung mereka (Al Kasani, 1982: 250). 
Dengan demikian, terjalinnya pernikahan seorang lelaki dengan wanita janda beranak, tidak lepas dari peran dan dukungan anak tirinya. Tanpa dukungan mereka bisa saja ia tidak akan pernah bisa menikahi janda tersebut.

Rasulullah șallallahu 'alaihi wa sallam mencontohkan sikap yang tepat bagaimana membalas budi anak-anak tiri beliau, bukan sekedar bersikap baik kepada mereka, namun juga berusaha membalas peran mereka yang sangat dominan dalam terjalinnya pernikahan beliau dengan ibu kandung mereka.

Menurut banyak ulama' di antaranya Imam Ibnu Abdil Bar, Al Qurțubi, Ibnu Kașir dan juga Ibnu Ḥajar, bahwa yang berperan menjadi wali pada pernikahan Rasulullah sallallahu 'alaihi wa sallam dengan Ummu Salamah ialah putranya yang bernama Salamah (Al Qurtubi, 2003: 78).

Karena itu, pada beberapa riwayat dikisahkan bahwa Rasulullah șallallahu 'alaihi wa sallam menikahkan Salamah bin Abi Salamah dengan 'Umārah bintu Ḥamzah bin 'Abdil Muțtalib, putri saudara sepupu beliau, selanjutnya beliau bersabda:

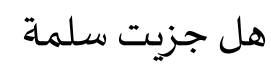

Apakah aku telah membalas budi Salamah (bin Abi Salamah)?(Al Baihaqi, 1344: 121)

Dan kalaupun anak tiri tidak dapat menjalankan peran sebagai wali, sebagaimana itu adalah pendapat yang diajarkan dalam Mazhab Imam Syāfi'i, namun sering kali seorang wanita janda enggan untuk menikah lagi dengan lelaki lain agar dapat fokus mengasuh anak-anaknya.

Ditambah lagi banyak janda yang mengkhawatirkan hubungan anak-anaknya dengan ayah tiri mereka kelak. Kebuntuan interaksi antara anak-anaknya dengan suami barunya, dapat menjerumuskannya dalam dilema yang berat untuk ia pecahkan. Karena kekhawatiran itu, sering kali seorang janda lebih memilih untuk tetap menjanda walaupun ia juga menyadari itu adalah pilihan yang berat (Arifin, 2019: 21).

Mencermati kembali kisah pernikahan Rasulullah șallallahu 'alaihi wa sallam dengan Ummi Salamah, pertimbangan ini adalah salah satu alasan yang beliau utarakan. Andai Rasulullah șallallahu 'alaihi wa sallam tidak memberi solusi untuk permasalahan anak-anak Ummu Salamah, bisa saja beliau batal menikah dengannya.

Dan pada kisah lain, Rasulullah șallallahu 'alaihi wa sallam benar-benar terhalangi dari menikahi wanita yang beliau cintai karena alasan ini. Sahabat Ibnu 'Abbas radiallahu 'anhu 
mengisahkan bahwa suatu hari Nabi sallallahu 'alaihi wa sallam melamar saudari sepupunya, yaitu Fākhitah Ummu Hāni’. Menanggapi lamaran tersebut, Ummu Hāni’ berkata:

$$
\text { والله أني كنت لأحبك في الجاهلية فكيف في الإسلام ولكني امرأة مصبية فأكره أن يؤذوك }
$$

Sungguh demi Allah, sejatinya ku telah mencintaimu sejak zaman jahiliyah (sebelum beragama Islam), bagaimana lagi halnya setelah aku beragama Islam, namun saat ini aku adalah wanita yang memiliki anak banyak, dan aku khawatir mereka akan mengganggumu. (An Naisaburi, 1998: 70)

Kagum dengan kasih sayang Ummu Hāni’ kepada putra-putrinya yang begitu besar, Rasulullah șallallahu 'alaihi wa sallam bersabda:

$$
\text { خير ذساء ركبن الإبل نساء قريش أحناه على ولد في صغره ، وأرعاهعلى زوج في ذات يده }
$$

Sebaik-baik wanita yang menunggang onta adalah wanita Quraisy, paling penyayang kepada anak di saat ia masih kecil dan paling pandai menjaga harta suaminya. (AlBukhari, 1987: 1266)

Dengan memahami peran penting anak-anak tiri pada pernikahan dirinya dengan ibu atau ayah mereka, dapat menjadikan orang tua tiri bersikap dengan benar.

e. Kiat kelima: Mengharap pahala dari mengasuh anak yatim

Status janda sering kali bukan pilihan, namun musibah yang tidak dapat dielakkan. Wanita yang ditinggal mati oleh suami yang ia cintai, tentu saja menanggung beban yang sangat berat. Terlebih lagi bila ia memiliki anak keturunan yang masih kecil-kecil, sehingga masih membutuhkan pengasuhan dan biaya hidup yang cukup besar.

Wanita dan anak-anaknya, yang ditimpa musibah tersebut tentu patut untuk mendapat uluran tangan. Karena itu syari'at islam menjanjikan pahala yang besar bagi yang peduli dengan mengurusi janda dan anak yatim.

Apalagi bila janda dan anak yatim tersebut adalah keluarga dari orang yang memiliki jasa besar atau tokoh masyarakat, sebagaimana hal itu terjadi pada janda-janda yang dinikahi oleh Rasulullah șallallahu 'alaihi wa sallam.

Banyak dalil yang menjelaskan keutamaan menyantuni janda dan anak yatim, di antaranya sabda Rasulullah șallallahu 'alaihi wa sallam, berikut ini:

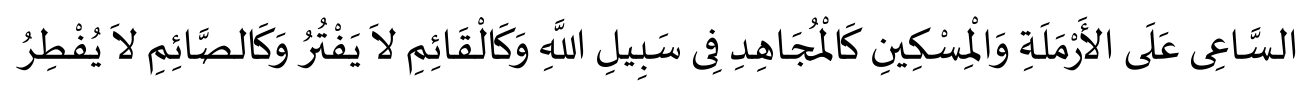


Orang yang menyantuni janda, dan orang miskin bagaikan seorang mujahid di jalan Allah, dan bagaikan orang yang selalu shalat sepanjang malam tiada kenal lelah, dan bagaikan orang yang selalu berpuasa tanpa penah berhenti. (Al-Bukhari, 1987: 221)

Pada hadiṣ lain, beliau menjelaskan keutamaan menyantuni anak yatim, dengan bersabda;

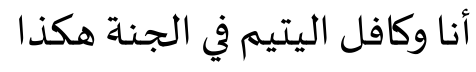

Kedudukanku di surga dan kedudukan orang yang menyantuni anak yatim bagaikan kedua jariku ini (sangat berdekatan). (Al-Bukhari, 1987: 2023)

Janda dan anak yatim dalam banyak kasus saling bertautan sehingga orang yang menikahi janda akan berinteraksi dengan anak yatim. Keberhasilan berinteraksi dengan anak-anak yatim tersebut sering kali menjadi kunci kedamaian rumah tangga.

Istri tidak akan pernah merasakan kedamaiaan dalam berumah tangga, bila anakanaknya dari suami sebelumnya yang telah meninggal dunia terlunta-lunta at au disia-siakan oleh suaminya.

Lelaki yang memutuskan untuk menikahi janda beranak, seharusnya memahami hal ini. Sepatutnya ia memperlakukan mereka bagaikan anaknya sendiri, mengingat keharmonisan rumah tangganya sangat bergantung kepada keberhasilannya dalam berinteraksi dengan anak-anak tirinya. Sikap ini nampak dengan jelas pada komitmen Rasulullah șallallahu 'alaihi wa sallam ketika beliau melamar Ummu Salamah radiallahu 'anha. Beliau bersabda :

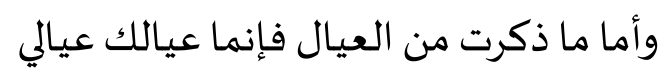

Adapun alasan yang engkau sebutkan perihal anak anakmu, maka sesungguhnya anak anakmu bagaikan anak anakku sendiri. (Al-Syaibani: 27)

f. Kiat keenam: Kasih sayang kepada anak tiri adalah bagian dari kesetiaan kepada orang tua mereka

Rumah tangga yang damai, sakinah nan mawaddah tidak mungkin terwujud kecuali dengan sinergi yang harmonis antara suami dan istri. Rumah tangga yang harmonis hanya menjelma dalam mimpi saja, bila salah satu dari suami atau istri berada dalam tekanan batin yang tiada pernah ada akhirnya. Salah satu biangtekanan batin yang berat baginya ialah bila ia harus memilih antara mempertahankan rumah tangganya atau membahagiakan anak keturunannya dari pernikahan sebelumnya. 
Tiada pilihan bagi keduanya untuk saling menyayangi dan berusaha sekuat tenaga mewujudkan kebahagiaan pasangan hidupnya. Karena kebahagian suami sejatinya hanya bisa terwujud bila istrinya, demikian pula sebaliknya. Karena itu dalam Al Qur'an pasangan suami dan istri diperumpamakan bagaikan pakaian. Ilustrasi ini menggambarkan bahwa idealnya suami melindungi, menghiasi dan melengkapi istri, dan sebaliknya juga demikian. Allah Ta'ala berfirman:

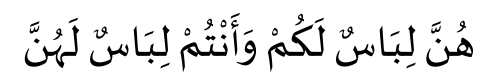

Mereka itu adalah pakaian bagimu, dan kamu pun adalah pakaian bagi mereka. (Q.S. Al Baqarah: 187)

Ahli tafsir menjelaskan bahwa istri adalah tempat bagi suaminya mendapatkan kedamaian hidup, sebagaimana suami adalah tempat bagi istrinya mendapatkan kedamaian hidup (Ibnu Kasir, 1999: 510).

Di antara kiat membahagiakan pasangan hidup ialah menjadikan orang-orang yang ia cintai merasakan kebahagiaan. Di antara hal yang menjadikan suami atau istri merasakan kebahagiaan adalah bila pasangannya memuliakan semua orang yang disayangi oleh suami atau istrinya.

Dinyatakan pada satu riwayat bahwa:

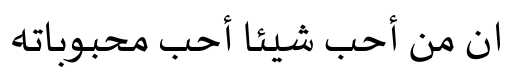

Siapapun mencintai sesuatu, niscaya ia mencintai semua yang dicintai oleh kekasihnya. (Al-Asqalani, 1379: 140)

Wajar bila dahulu Rasulullah șallallahu 'alaihi wa sallam senantiasa memuliakan kerabat dan kawan istri-istri beliau. 'Aisyah radiallahu 'anha mengisahkan bahwa suatu hari datang seorang wanita tua menjumpai Rasulullah shallallahu 'alaihi wa sallam. Setelah beliau mengenali wanita itu, beliau begitu perhatian dan memuliakannya. Ketika wanita tua itu telah pergi, segera 'Aisyah mempertanyakan sikap beliau kepada wanita tua itu. Beliau menjawab

$$
\text { إنها كانت تأتينا زمن خديجة وإن حسن العهد من الإيمان }
$$

Sesungguhnya wanita itu dahulu semasa hidup Khadijah sering mengunjungi kami, dan sesungguhnya kesetiaan itu adalah bagian dari iman. (An-Naisaburi, 1998: 165)

Bila demikian sikap Rasulullah șallallahu 'alaihi wa sallam kepada kawan istri beliau, maka sudah barang tentu kepada kerabat istri beliau lebih pantas untuk dimuliakan. 
Suatu hari Hālah bin Abi Hālah, putra tertua Khadijah raḍiallahu 'anhuma, datang ke rumah Rasulullah shallallahi 'alaihi wa sallam di saat beliau sedang tidur. Mendengar kedatangan Hālah, salah satu anak tiri beliau, beliau segera bangun dari tempat tidurnya dan memeluk Hālah dengan erat sambil menyebut-nyebut namanya: Hālah, Hālah, Hālah. Beliau nampak begitu girang dengan kedatangan Hālah ini, karena ia adalah salah satu putra Khadijah radiallahu 'anhuma(An Naisaburi, 1998: 845).

Sikap yang sama juga beliau tunjukkan kepada saudari kandung Khadijah radhiallahu 'anha yang kebetulan juga bernama Hālah bintu Khuwailid. Tatkala beliau mendengar suara Hālah meminta izin, beliau nampak begitu girang, lalu bersabda:

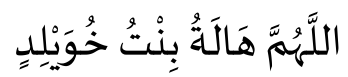

Ya Allah, semoga yang datang adalah Hālah bintu Khuwailid. (Al-Bukhari, 1987: 1389)

Berbagai data di atas, menggambarkan bahwa Rasulullah șallallahu 'alaihi wa sallam bukan hanya menerima keberadaan anak tiri dalam rumah tangga beliau. Lebih jauh, beliau benar-benar memuliakan mereka karena berbuat baik kepada mereka adalah bagian dari kesetiaan kepada istrinya.

\section{KESIMPULAN}

Penelitian ini bertujuan untuk mengungkap keteladanan Rasulullah șallallahu 'alaihi wa sallam dalam berinteraksi dengan anak-anak tiri beliau. Dengan terungkapnya berbagai keteladanan tersebut, besar harapannya dapat diaplikasikan oleh orang tua tiri, sehingga sukses merajut rumah tangga yang harmonis, tanpa terganggu oleh keberadaan anak tiri dalam rumah tangganya.

Dari bebagai data yang berhasil dirangkum oleh peneliti terungkap sekurang kurangnya ada enam kiat efektif yang dicontohkan oleh Rasulullah șallallahu 'alaihi wa sallam dalam berinteraksi dengan anak-anak tiri beliau.

Dengan mencermati keenam kiat yang telah dijabarkan pada penelitian ini, terungkap bahwa kebahagiaan anak tiri adalah salah satu pondasi terwujudkan rumah tangga yang harmonis orang tua tiri mereka dengan ayah atau ibu kandung mereka.

Sungguh kesalahan besar bila ada yang beranggapan bahwa keberadaan anak tiri dalam keluarga hanyalah ancaman bagi keutuhan rumah tangga seseorang. Di antara persepsi keliru 
bila ada yang beranggapan bahwa anak-anak tiri tiada memiliki kontribusi apapun bagi keluarga orang tua tiri mereka.yang harmonis. Wallahu a'alam bisṣowab

\section{E. DAFTAR PUSTAKA}

Arifin, Muhammad. "Implikasi Dilematis Status Janda Bagi Wanita".Al Majaalis: Jurnal Dirasat Islamiyah.Vol. 6, No 2, 2019.

Al 'Asqalāni, Ahmad bin Ali.Fathul Bāri Syarah Șaḥị̣ Al Bukhāri. Baerūt: Dār Al Ma'rifah, $1379 \mathrm{H}$.

Al Bukhāri, Muhammad bin Ismā’il.Ṣahịḥ Al Bukhāri.Beirūt: Dār Ibnu Kaṣīr, 1987.

Al Busty, Muhammad bin Ḥibbāan. Saḥị̣ Ibnu Hibbān. Baerūt: Muassasah Ar Risālah1993.

Al Baihaqy, Ahmad bin Husain.As Sunan Al Kubra.t.t.: Haedar Abād, 1344 H.

Al Fauzān, Ṣaleh bin Fauzān. At Tahqqiqāt Al Marḍiyah Fi Al Mabāhịị Al faraḍiyah. Riyaḍ: Maktabah Al Maārif, 1987.

Al Ghazāli, Muhammad bin Muhammad.Al Mustashfa Fi 'Ilmi Ușul Al Fiqhi.Baerūt: Dār ‘'̄lam Al Kutub, 1413.

Ibnu Abdil Bar, Yūsuf bin Abdillah. Al Istii'aabFi Ma'rifati Al Aṣ̣āō. Al Maktabah Syamilah.

Ibnu Kas̄ìr, Ismā’il bin 'Umar. Al Bidāyah wa An Nihāyah. Kairo: Dār Ar Rayyan, 1988.

Ibnu Kas̄ìr, Tafsir Al Qur’an Al ‘Ažīim. Cet. II;t.t.: Dār At Ṭaibah Li An Nasyer wa At Tauziii’, 1999.

Ibnu Kholdūn, Abdurrahmān. Al 'Ibar wa Dīwān Al Mubtada' wa Fi Ayyami Al 'Arab wa Al 'Ajam wa Al Barbar wa Man 'Āṣarahum min Zawi As Sultān Al Akbar.Beirūt: Dār Ihyāu At Turaș Al 'Arabi, t.th.

Ibnu Mājah, Muhammad bin Yazīd.Sunan Ibnu Mājah, Bairūt: Dār Ibnu Kaṣīr, t.th.

Ibnu Taimiyyah, Ahmad bin Abdul Halim.Majmu' Fatawa. Madinah Munawwarah: Majma' Al Malik Fahed li Thiba'ati Al Qur'an Al Karim, t.th.

Al Kasāni, 'Alāuddin.Badā'ii As Sanā'ii Fi Tartīb As Syarāi’i. Baerūt: Dār Al Kitāb Al ‘Arabi, 1982.

Al Maqdisi, Abdullah bin Ahmad. Al Mughni Ibnu Qudamah.Baerūt: Dār 'Ālam Al Kutub,1997 . 
Al Māwardi, Ali bin Muhammad. Al HāāwiAl Kabīr. Baerūt: Dār Al Fikr, 1994.

Al Mubarakfur, Șafiyurrahmān.Ar Rakhiq Al Makhtum.t.t.: Dār Ihyāu At Turāṣ Al 'Arabi, t.th.

Al Naisābūri, Muhammad bin Abdillah.Al Mustadrak 'Ala As Sahihain.Baerūt: Dār Al Ma'rifah, 1998.

Al Naisābūri, Muslim bin Al Hajajāj.Saḥīh Muslim. Beirūt: Dār Al Jil, t.th.

Noviana, Ivo.Ejournal Kemsos RI.t.t.: Pusat Penelitian dan Pengembangan Kesejahteraan Sosial, Kementerian Sosial RI. 2015.

Al Sajistāni, Abu Dāwud, Sulaimān bin Al Asy’aṣ. Sunan Abu Dāwud. Bairūt: Dār Al Kitāb $\mathrm{Al}$ 'Arabi, t.th.

Al Syaibāni, Aḥmad bin Ḥambal.Al Musnad. Kairo: Muassasah Al Qurṭubah, t.th.

Al Syarbīni, Muhammad Al Khațīb.Mughni Al MuhtajIla Ma’rifati Al Fāz Al Minhāj.Baerūt: Dār Al Fikr, t.th.

Al Tirmizy, Muḥammad bin 'Isa.Sunan At Tirmizy. Bairūt: Dār Ihyā' At Turāṣ Al 'Arabi, t.th.

Al 'Ufi, 'Awạ̣ bin Rajā'. Al Wilāyah Fi An Nikāh. t.t.: Islamic University Of Madinah,1423 $\mathrm{H}$. 